\title{
Development of zygotic and germline gene drives in mice
}

Chandran Pfitzner ${ }^{1,2}$, James Hughes ${ }^{1}$, Melissa White ${ }^{2,3,4}$, Michaela Scherer ${ }^{2,3,4}$, Sandra Piltz ${ }^{2,3,4}$ \& Paul Thomas ${ }^{2,3,4}$

\author{
Affiliations \\ ${ }^{1}$ School of Biological Sciences, The University of Adelaide, Adelaide, South Australia, \\ Australia, 5005 \\ 2 Precision Medicine, South Australian Health and Medical Research Institute, Adelaide, \\ South Australia, Australia, 5000 \\ ${ }^{3}$ School of Medicine, The University of Adelaide, Adelaide, South Australia, Australia, 5005 \\ ${ }^{4}$ Robinson Research Institute, The University of Adelaide, Adelaide, South Australia, \\ Australia, 5005
}

\section{Abstract}

CRISPR-based synthetic gene drives have the potential to deliver a more effective and humane method of invasive vertebrate pest control than current strategies. Relatively efficient CRISPR gene drives have been developed in insects and yeast but not in mammals. Here we investigated the efficiency of CRISPR/Cas9-based gene drives in Mus musculus by constructing "split drive" systems with Cas9 under the control of zygotic (CAG) or germline (Vasa) promoters. While both systems generated double stranded breaks at their intended target site in vivo, no homing was detectable. Our data indicate that robust and specific Cas9 expression during meiosis is a critical requirement for the generation of efficient CRISPR-based synthetic gene drives in rodents.

\section{Introduction}

Invasive rodents, including mice, pose a significant threat to biodiversity, particularly on islands, and are the likely cause of many species extinctions (Blackburn et al. 2004; Harris 2008; Doherty et al. 2016). The economic burden to the agriculture industry is also considerable, costing tens of millions of dollars to many countries each year (Stenseth et al. 2003). Previous attempts at invasive vertebrate pest control have had some success, but there are still many challenges including cost and ethical considerations (Gregory et al. 2014).

Manipulation of natural gene drives has been proposed as a tool for population suppression of invasive rodent pests by rapidly spreading a gene through a wild population that would ultimately have a deleterious effect on reproductive fitness. These include transposable elements (TEs), homing endonuclease genes (HEGs) and meiotic drives. However, all these have significant drawbacks; TEs copy themselves to unpredictable locations causing their own repression or disruption of endogenous genes (Sinkins and Gould 2006), HEGs are not found in animals and rely on a site-specific nuclease that can't be tailored to a specific location (Burt and Koufopanou 2004) and meiotic drives are rare, poorly understood and generally very large, making them difficult to manipulate (Kelemen and Vicoso 2018; Charron et al. 2019). 
bioRxiv preprint doi: https:/doi.org/10.1101/2020.06.21.162594: this version posted June 21,2020 . The copyright holder for this preprint (which was not certified by peer review) is the author/funder, who has granted bioRxiv a license to display the preprint in perpetuity. It is made available under aCC-BY-NC-ND 4.0 International license.

Synthetic, clustered regularly interspaced short palindromic repeats (CRISPR)-based gene drives provide an alternative that has a small genomic footprint, can be inserted almost anywhere in the genome and can be created relatively quickly and easily. CRISPR gene drives are composed of a cassette integrated into a specific genomic site that expresses CRISPR-associated protein 9 (Cas9) endonuclease and a customisable guide RNA (gRNA) designed to cut the homologous WT locus. Repair of the double stranded break (DSB) by homology directed repair (using the gene drive allele as a repair template) results in conversion of the WT allele to a gene drive allele, in a process termed "homing", which renders the cell homozygous for the gene drive allele. Homing can be restricted to the gamete precursors resulting in selective homozygosity in the germline whilst the somatic cells remain heterozygous. The homing event will ensure that the gene drive allele will be present in all of the gametes and will be transmitted to all of that organism's progeny. Thus, over several generations, gene drives will rapidly spread through a given population. Alternatively, repair of the DSB by error-prone pathways such as non-homologous end joining, microhomology-mediated end joining and single-strand annealing can generate an indel that interrupts the gRNA binding sequence thereby creating a mutant allele that is immune to homing. These so called "resistant" alleles pose a significant barrier to gene drive spread (Prowse et al. 2017).

Highly efficient CRISPR gene drives have already been generated in the following species, where germline homing rates (in brackets) are defined as the percentage of WT alleles converted to gene drive alleles: Drosophila melanogaster (>76\%) (Gantz and Bier 2015; Champer et al. 2017), Anopheles stephensi (>96\%) (Gantz et al. 2015), Saccharomyces cerevisiae (>99\%) (DiCarlo et al. 2015) and Anopheles gambiae (>82\%) (Hammond et al. 2016). While gene drives are yet to be developed in mice, Grunwald et al. (2019) recently generated a "single generation" homing system. Highly variable and relatively inefficient (0$72 \%$ ) homing was observed in females but no homing was detected in males. While this study suggests that it may be possible to develop deployable gene drives in mice, key components including the choice of promoter for Cas9 expression are yet to be assessed.

Here, we describe the first attempt to develop mice with functional, multi-generational gene drives under the control of either zygotic or germline promoters. To ensure that the mice we generated did not pose any threat to the environment if unintentionally released (Akbari et al. 2015), we employed a "synthetic target" strategy as a molecular safeguard. In addition, we used a "split drive" system where Cas9 is completely separated from the gRNAcontaining homing cassette.

\section{Materials and Methods}

\section{Mouse Model Generation}

Cas9 mRNA for zygotic injections was generated from the Xhol-digested pCMV/T7-hCas9 plasmid (Toolgen) using the mMESSAGE mMACHINE ${ }^{\circledR}$ T7 ULTRA Transcription Kit (Ambion) and purified using RNeasy Mini Kit (Qiagen).

The Tyr-gRNA for zygotic injection of constructs targeting Tyrosinase (Tyr) intron 1 was designed using the Zhang lab tool (Hsu et al. 2013). The Rosa26-gRNA design was previously published (Platt et al. 2014). gRNA-containing plasmids were generated in pSpCas9(BB)-2APuro (PX459) V2.0 (Addgene; 62988) (Ran et al. 2013) with guide oligonucleotides purchased from Sigma/IDT. gRNA was generated with T7 promoter-containing oligos 
bioRxiv preprint doi: https:/doi.org/10.1101/2020.06 21.162594: this version posted June 21,2020 . The copyright holder for this preprint (which was not certified by peer review) is the author/funder, who has granted bioRxiv a license to display the preprint in perpetuity. It is made available under aCC-BY-NC-ND 4.0 International license.

(Sigma/IDT) using HiScribe ${ }^{\text {TM }}$ T7 Quick High Yield RNA Synthesis Kit (NEB) and purified using RNeasy Mini Kit (Qiagen).

The Tyr ${ }^{\text {gRNA-Tomato }}$ plasmid was purchased from GenScript and prepared using PureLink ${ }^{\mathrm{TM}}$ HiPure Plasmid Midiprep Kit (Invitrogen). Plasmid (10 ng/ $\mu \mathrm{L})$, Cas9 mRNA ( $25 \mathrm{ng} / \mu \mathrm{L})$, and Tyr-gRNA (10 ng/ $\mu \mathrm{L}$ ) were injected into the pronuclei of C57BL/6J zygotes, transferred to pseudo-pregnant recipients, and allowed to develop to term.

An unanticipated side effect of the presence of the Tyr ${ }^{\text {gRNA-Tomato }}$ allele resulted in the sudden and largely unexplained deaths of mice carrying that allele. Due to the ethical concerns surrounding this unexpected toxicity, the Tyr ${ }^{\text {gRNA-Lite }}$ mouse was designed and generated, containing only the U6-Neo-gRNA cassette from the Tyr ${ }^{\text {gRNA-Tomato }}$ mouse.

Tyr ${ }^{\text {gRNA-Lite }}$ ssDNA was purchased from IDT as a Megamer ${ }^{\circledR}$. ssDNA (10 ng/ $\left.\mu \mathrm{L}\right)$, PNA Bio Cas9 protein $(50 \mathrm{ng} / \mu \mathrm{L})$ and Tyr-gRNA $(25 \mathrm{ng} / \mu \mathrm{L})$ were injected into the pronuclei of $\mathrm{C} 57 \mathrm{BL} / 6 \mathrm{~J}$ zygotes, transferred to pseudo-pregnant recipients, and allowed to develop to term.

Tyr ${ }^{\text {Target }}$ dsDNA was purchased from IDT. dsDNA (100 ng/ $\left.\mu \mathrm{L}\right)$, cas9 mRNA (12.5 $\mathrm{ng} / \mu \mathrm{L}$ ) and Tyr-gRNA ( $5 \mathrm{ng} / \mu \mathrm{L}$ ) were injected into the cytoplasm of C57BL/6J zygotes, transferred to pseudo-pregnant recipients, and allowed to develop to term.

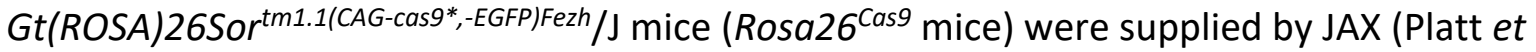
al. 2014).

Vasa-Cas9 dsDNA was constructed as follows. Gibson assembly was used to clone the Vasa$\beta$-globin-II fragment from the Vasa-Cre plasmid (Addgene; 15885) (Gallardo et al. 2007) and the Cas9-BGH fragment from pSpCas9(BB)-2A-Puro (PX459) V2.0 (Addgene; 62988) (Ran et al. 2013) into the pStart-K plasmid (Addgene; 20346) (Wu et al. 2008). This plasmid was expanded with PureLink ${ }^{\mathrm{TM}}$ HiPure Plasmid Midiprep Kit (Invitrogen), digested with BamHI (NEB), purified using Gel DNA Recovery Kit (Zymoclean), and further purified on a floating dialysis membrane for $2.5 \mathrm{~h}$. dsDNA (3 ng/ $\mu \mathrm{L}$ ), PNA Bio Cas9 protein (50 ng/ $\mu \mathrm{L}$ ) and Rosa26gRNA ( $25 \mathrm{ng} / \mu \mathrm{L}$ ) were injected into the pronuclei of $\mathrm{C} 57 \mathrm{BL} / 6 \mathrm{~J}$ zygotes, transferred to pseudo-pregnant recipients, and allowed to develop to term.

\section{Mouse crosses}

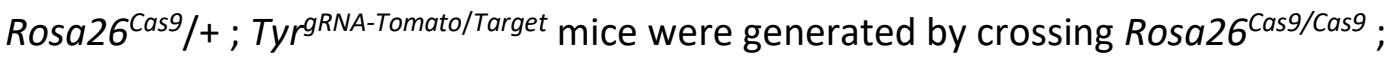
Tyr $^{\text {Target/Target }}$ mice to Tyr ${ }^{\text {gRNA-Tomato }} /+$ mice and also by crossing Rosa26 $6^{\text {Cas9/Cas9 }} ;$ Tyr $^{\text {gRNA- }}$ Tomato/+ mice to Tyr ${ }^{\text {Target/Target }}$ mice.

Vasa-Cas9-2/+ ; Tyr ${ }^{\text {RNA-Tomato/Target }}$ mice were generated by crossing Vasa-Cas9-2/Vasa-Cas92 ; Tyr ${ }^{\text {Target/Target }}$ mice to Tyr ${ }^{\text {gRNA-Tomato }} /+$ mice. Vasa-Cas9-4/+ ; Tyr ${ }^{\text {gRNA-Lite/Target }}$ mice were generated by crossing Vasa-Cas9-4/+ ; Tyr ${ }^{\text {Target/Target }}$ mice to Tyr ${ }^{\text {gRNA-Lite/gRNA-Lite mice. }}$

Sequencing of Tyr ${ }^{\text {Target }}$ loci in Vasa-Cas9-2/+ ; Tyr ${ }^{\text {GRNA-Tomato/Target }}$ and Vasa-Cas9-4/+ ; Tyr $^{\text {gRNA-Lite/Target }}$ mice confirmed no carryover of maternal Cas 9 mRNA into eggs as no indels were seen.

\section{DNA extractions}

gDNA was extracted from embryo, tail tip, or ear notch biopsies using the High Pure PCR Template Preparation Kit (Roche), KAPA Express Extract kit (Roche), or MyTaq ${ }^{\mathrm{TM}}$ Extract-PCR Kit (Bioline). gDNA was prepared from blastocysts in a $20 \mu \mathrm{L}$ solution of $185.5 \mathrm{mM} \mathrm{pH} 8.3$ Tris- $\mathrm{HCl}, 185.5 \mathrm{mM} \mathrm{KCl}, 7.4 \times 10^{-6} \%$ gelatin, $8.3 \times 10^{-4} \%$ Polysorbate $20,1.48 \%$ tRNA from 
bioRxiv preprint doi: https:/doi.org/10.1101/2020 06.21.162594: this version posted June 21, 2020. The copyright holder for this preprint (which was not certified by peer review) is the author/funder, who has granted bioRxiv a license to display the preprint in perpetuity. It is made available under aCC-BY-NC-ND 4.0 International license.

Page 4 of 14

baker's yeast (Sigma), $1.15 \mathrm{mg} / \mathrm{mL}$ Proteinase $\mathrm{K}$ (Thermo Scientific) which was incubated at $56{ }^{\circ} \mathrm{C}$ for $10 \mathrm{~min}$ and $95^{\circ} \mathrm{C}$ for $10 \mathrm{~min}$.

gDNA was prepared from sperm by washing epididymides in PBS at $37{ }^{\circ} \mathrm{C}$ followed by transfer to the centre well of a $37{ }^{\circ} \mathrm{C}$ Center-Well Organ Culture Dish (Falcon) containing 500 $\mu \mathrm{L}$ of $\mathrm{M} 2$ medium (Sigma) in the centre well and $3 \mathrm{~mL}$ of PBS in the outer well. Several incisions were made across epididymides before incubating at $37{ }^{\circ} \mathrm{C} / 5 \% \mathrm{CO}_{2}$ for $5 \mathrm{~min}$. The sperm-containing M2 medium was then centrifuged at $400 \mathrm{RCF}$ for $10 \mathrm{~min}$. The supernatant was discarded, $500 \mu \mathrm{L}$ PBS was added and then centrifuged at 8000 RCF for $1 \mathrm{~min}$. The supernatant was discarded and the pellet resuspended in $100 \mu \mathrm{L}$ PBS. $400 \mu \mathrm{L}$ Tissue Lysis Buffer (Roche) and $50 \mu \mathrm{L}$ Proteinase $\mathrm{K}$ (Roche) was added and the solution was vortexed. The solution was then incubated at $55^{\circ} \mathrm{C}$ for $1 \mathrm{~h}, 50 \mu \mathrm{L}$ of $1 \mathrm{M} \mathrm{DTT}$ was added, vortexed rigorously, then incubated $\mathrm{O} / \mathrm{N}$ at $55^{\circ} \mathrm{C}$. High Pure PCR Template Preparation Kit (Roche) was then used for DNA extraction, eluting in $80 \mu \mathrm{LEB}$.

\section{RNA Extraction}

Acid guanidinium thiocyanate-phenol-chloroform RNA extraction was performed on testes, ovaries, and spleens. RNA was purified using the RNeasy Mini/Micro kit (Qiagen) in conjunction with RNase-Free DNase Set (Qiagen). cDNA was generated using the HighCapacity RNA-to-cDNA ${ }^{\mathrm{TM}}$ Kit (Applied Biosystems).

\section{Genotyping Analysis}

PCRs were performed using either Taq DNA Polymerase (Roche), Phusion HF DNA Polymerase (NEB) or KAPA2G Fast Genotyping Mix (Roche) using their associated buffers or alternatively FailSafe PCR PreMix buffers (Epicentre). Fast SYBR Green Master Mix (Applied Biosystems) was used for qPCRs. Primers were purchased from IDT and Sigma. All primers used are shown in Supplemental Table 3.

50 ng genomic DNA was digested with Msel for droplet digital PCR (ddPCR). ddPCR was performed with $12.5 \mathrm{ng}$ digested DNA, $1.25 \mu \mathrm{L}$ of control assay targeting Rpp30 (Bio-Rad), $1.25 \mu \mathrm{L}$ of target assay targeting U6-Neo-gRNA (Bio-Rad) and $12.5 \mu \mathrm{L}$ ddPCR Supermix for Probes (No dUTP) (Bio-Rad). Droplets were generated with QX200 Droplet Generator (BioRad) and read with QX200 Droplet Reader (Bio-Rad).

Sanger sequencing was performed by Australian Genome Research Facility (Adelaide, Australia).

Indels at Tyr ${ }^{\text {Target }}$ were detected by RFLP in combination with T7 Endonuclease digestion to cleave heteroduplexes.

\section{Results}

Design and generation of the homing system

To generate a "synthetic target" site, we identified a candidate homing gRNA (Neo-gRNA) targeting the bacterial kanamycin kinase gene and confirmed its on-target cleavage activity using embryonic stem cells harbouring that gene (Supplemental Figure 1). Next, we generated a "donor" mouse line (Tyr ${ }^{\text {gRNA-Tomato }}$ ) by inserting a Neo-gRNA expression cassette (Cong et al. 2013) and a ubiquitous dTomato reporter gene (Shaner et al. 2004) into the first intron of the Tyr gene (Figure 1A, Supplemental Figure 2A,B). To generate a null allele, we included a 3x SV40 polyadenylation signal in the same orientation as Tyr so that the Tyr 
transcript is subject to premature termination. Inactivation of Tyr was confirmed by the

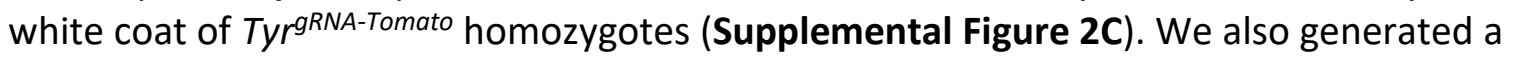
complementary "receiver" mouse line (Tyr ${ }^{\text {Target }}$ ) with the Neo-gRNA target sequence at the

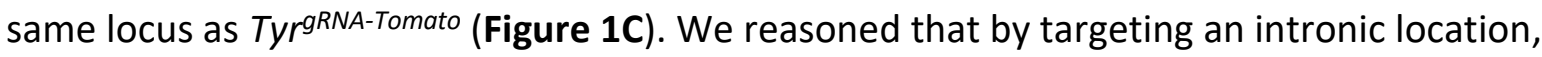
indel mutations generated by error-prone repair pathways would not significantly reduce tyrosinase (TYR) function. Therefore, conversion of the Tyr ${ }^{\text {Target }}$ allele to a Tyr ${ }^{\text {gRNA-Tomato }}$ allele via zygotic homing would generate a white mouse whereas error-prone repair pathways would generate a black mouse. As expected, the Tyr Target insertion did not detectably alter TYR activity as demonstrated by the black coat of Tyr ${ }^{\text {Target }}$ homozygous mice (Supplemental Figure 3).

To assess homing, Cas9 was expressed using a separate transgene. For zygotic homing we used Rosa26 $6^{\operatorname{Cas} 9}$ mice (Platt et al. 2014) which express Cas9 (and EGFP) ubiquitously (Figure 1D). For germline homing experiments we generated Vasa-Cas9 lines via random integration (Figure 1E). 
bioRxiv preprint doi: https:/doi.org/10.1101/2020.06 21.162594 this version posted June 21,2020 . The copyright holder for this preprint (which was not certified by peer review) is the author/funder, who has granted bioRxiv a license to display the preprint in perpetuity. It is made available under aCC-BY-NC-ND 4.0 International license.

Page 6 of 14

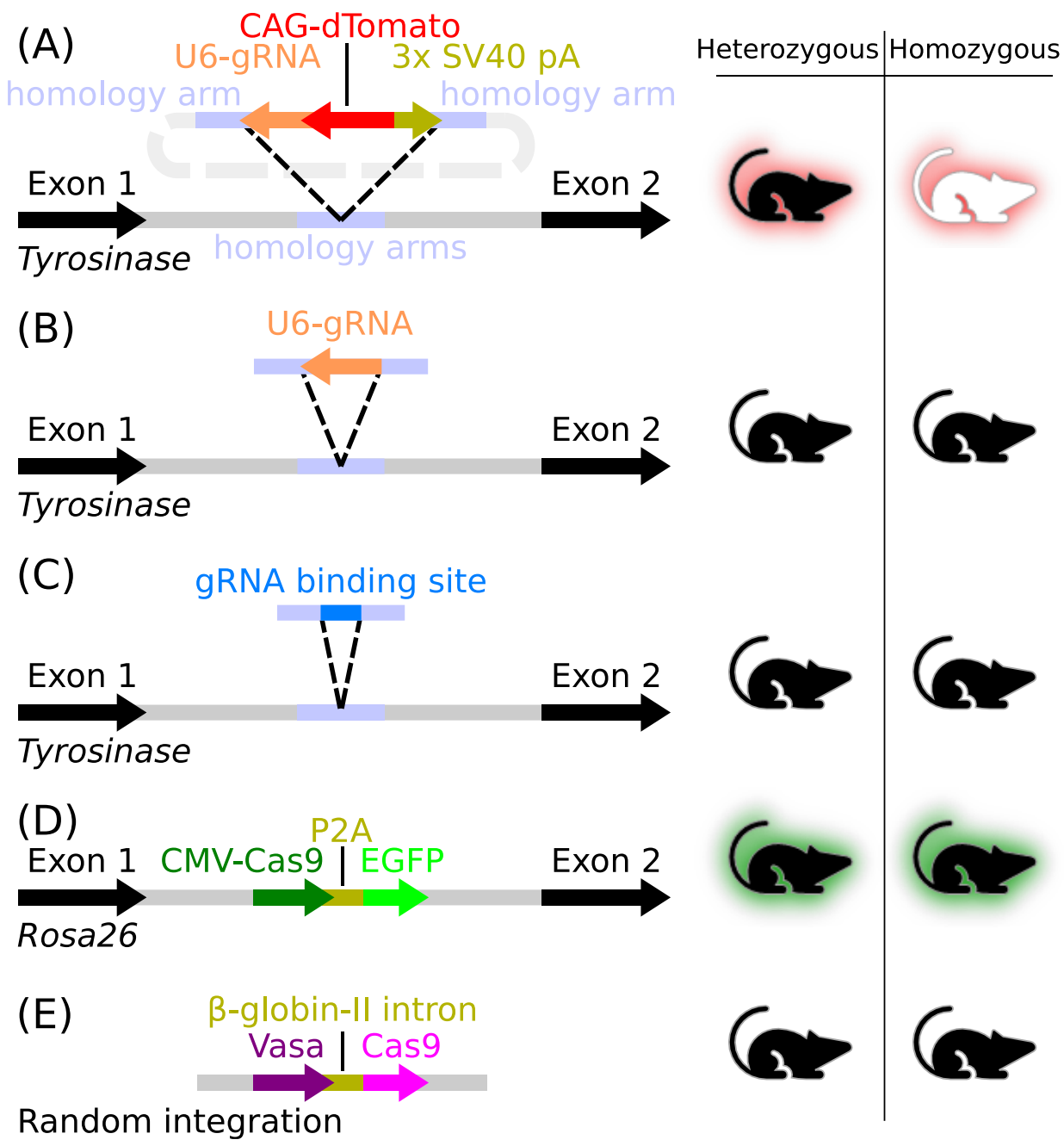

Figure 1. Mouse models. (A) Tyr ${ }^{\text {gRNA-Tomato }}$ mice contained a U6-driven Neo-gRNA, a CAG-driven dTomato gene and a 3x SV40 polyA signal inserted into Tyr intron 1. (B) Tyr ${ }^{\text {gRNA-Lite }}$ mice contained a U6-driven Neo-gRNA inserted into the same location as (A) in Tyr intron 1. (C) Tyr ${ }^{\text {Target }}$ mice contained the Neo-gRNA target sequence and NGG PAM inserted into the same location as (A) in Tyr intron 1. (D) The Rosa26 $6^{\text {Cas9 }}$ mouse contained a CAG-driven cas9 linked via P2A to EGFP in the Rosa26 locus (Platt et al. 2014). (E) The Vasa-Cas9 mouse lines contained a Vasa-driven hSpCas9 linked via the $\beta$-globin-II intron (non-targeted integration). Coat colour and fluorescence phenotypes are shown on the right.

\section{Zygotic homing}

To assess homing in the zygote, we generated 96 Rosa26 $6^{\text {Cas }} /+$; Tyr ${ }^{\text {RNA-Tomato/Target }}$ mice. Two groups were identified based on coat colour: black mice (88) and dappled mice (8). $94 \%$ $(83 / 88)$ of the black mice carried indels in the Tyr ${ }^{\text {Target }}$ allele indicating efficient production and high cleavage activity of the Neo-gRNA/Cas9 complex (Figure 2). To assess whether homing had occurred in some cells of the dappled mice, we quantitated the Tyr ${ }^{\text {gRNA-Tomato }}$ allele using ddPCR (Supplemental Figure 4). Surprisingly, only a single copy of the Tyr ${ }^{\text {gRNA-Tomato }}$ allele was present, indicating a lack of homing. Based on our previous observation that DSB repair in zygotes often generates large (>100 bp) deletions (Adikusuma et al. 2018), we amplified the target locus using primers distant from the cleavage site. Large deletions were identified in all dappled mice (Supplemental Figure 5). As Tyr exon 1 was $500 \mathrm{bp}$ upstream of the target site it seems likely that these deletions extended into exon 1 to generate null alleles consistent with the partial (mosaic) albino phenotype. 
bioRxiv preprint doi: https:/doi.org/10.1101/2020.06 21.162594 this version posted June 21,2020 . The copyright holder for this preprint (which was not certified by peer review) is the author/funder, who has granted bioRxiv a license to display the preprint in perpetuity. It is made available under aCC-BY-NC-ND 4.0 International license.

Page 7 of 14

Notably, multiple Tyr ${ }^{\text {Target }}$ indel alleles were also detected in many black mice (Figure 2) indicating mosaicism. Taken together, these data indicate that despite efficient cleavage of the target sequence, homing did not occur in zygotes or cleavage-stage embryos.
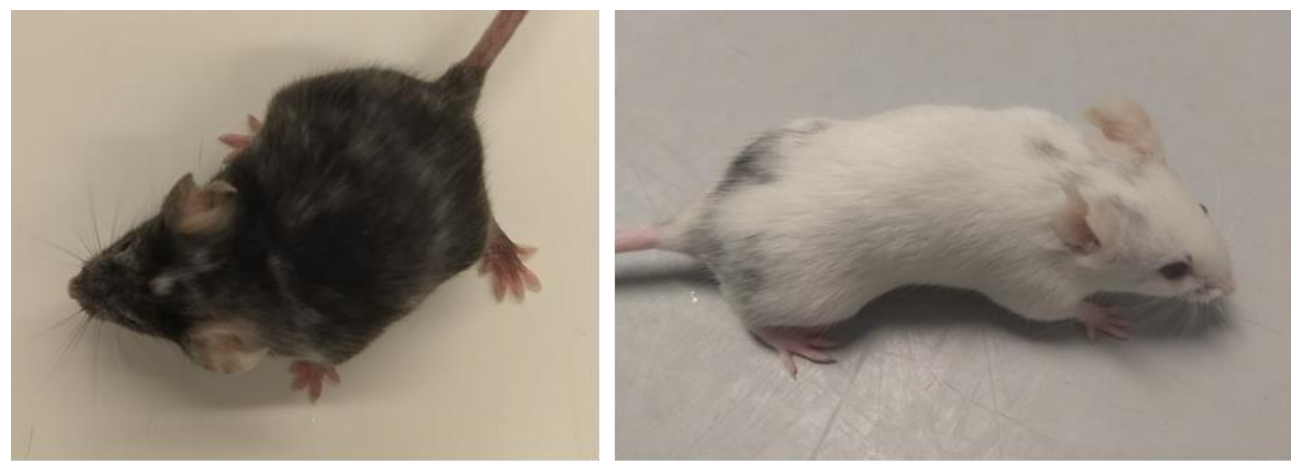

\begin{tabular}{|c|c|c|}
\hline & \multicolumn{2}{|c}{ Coat Colour } \\
\cline { 2 - 3 } Genotype & Black & Dappled \\
\hline Large $\Delta$ mosaic & 0 & 2 \\
\hline Indel & 17 & 0 \\
\hline Indel mosaic & 39 & 0 \\
\hline No activity/indel mosaic & 27 & 6 \\
\hline No activity & 5 & 0 \\
\hline & \multicolumn{2}{|c|}{ Totals } \\
\hline Any indel/large $\Delta$ & \multicolumn{2}{|c}{83} \\
No activity & \multicolumn{2}{|c|}{5} \\
\hline
\end{tabular}

Figure 2. Zygotic-homing gene drive results. Top: Representative Rosa26 $6^{\text {Cas } 9} /+;$ Tyr $^{\text {RRNA-Tomato/Target }}$ mice with dappled coats showing wide variability in mosaicism. Bottom: Table of genotypes of $T_{y} r^{\text {Target }}$ allele(s) in Rosa26 $6^{\text {Cas9 }} /+;$;yr ${ }^{\text {gRNA-Tomato/Target }}$ gene drive mice. "Large $\Delta$ mosaic" contain a large deletion and 1 or more indels. "Indel" contain a single indel. "Indel mosaic" contain 1 or more indels. "No activity/indel mosaic" contain an uncut Tyr Target allele and 1 or more indels/large deletions. "No activity" contain a single uncut Tyr ${ }^{\text {Target }}$ allele. Dappled is a mix of black and white fur.

\section{Germline homing}

For germline homing experiments, we initially generated a Vasa-Cas 9 transgenic mouse using the previously characterised $5.6 \mathrm{~kb}$ Vasa promoter fragment (Vasa-Cas9-2; Figure 1E) which has been shown to drive robust Cre expression in the male and female germline (Gallardo et al. 2007). RT-qPCR analysis showed that Cas9 was expressed in both testes and ovaries, although, unexpectedly, expression in the latter was extremely low (Supplemental Figure 6A). To assess germline homing, Vasa-Cas9-2/+ ; Tyr ${ }^{\text {RNA-Tomato/Target }}$ mice were generated and mated with WT partners. If homing occurs in the germline, $>50 \%$ of their progeny will carry the Tyr ${ }^{\text {gRNA-Tomato }}$ red fluorescence marker while no homing would result in $~ 50 \%$ transmission (Figure 3). Altogether we screened 355 offspring from 6 Vasa-Cas92/+ ; Tyr ${ }^{\text {gRNA-Tomato/Target }}$ males (119 offspring) and 12 Vasa-Cas9-2/+ ; Tyr ${ }^{\text {gRNA-Tomato/Target }}$ females (236 offspring; Figure 4, Supplemental Table 1). No significant increase $\left(\chi^{2}\right.$ test) in Ty ${ }^{\text {gRNA-Tomato }}$ transmission was observed in males $(53.8 \%, p=0.46)$ or females $(48.7 \%$, $\mathrm{p}=0.75$ ). To assess gRNA/Cas9 cleavage activity, non-fluorescent offspring were screened for indels in the Tyr Target allele by RFLP (Supplemental Figure 7, Supplemental Table 1). Only a low percentage of indels were present in progeny from both males $(14.5 \%)$ and females (9.3\%) with the majority of Tyr ${ }^{\text {Target }}$ alleles remaining uncut. 
bioRxiv preprint doi: https://doi.org/10.1101/2020.06 21.162594; this version posted June 21, 2020. The copyright holder for this preprint (which was not certified by peer review) is the author/funder, who has granted bioRxiv a license to display the preprint in perpetuity. It is made available under aCC-BY-NC-ND 4.0 International license.

Page 8 of 14

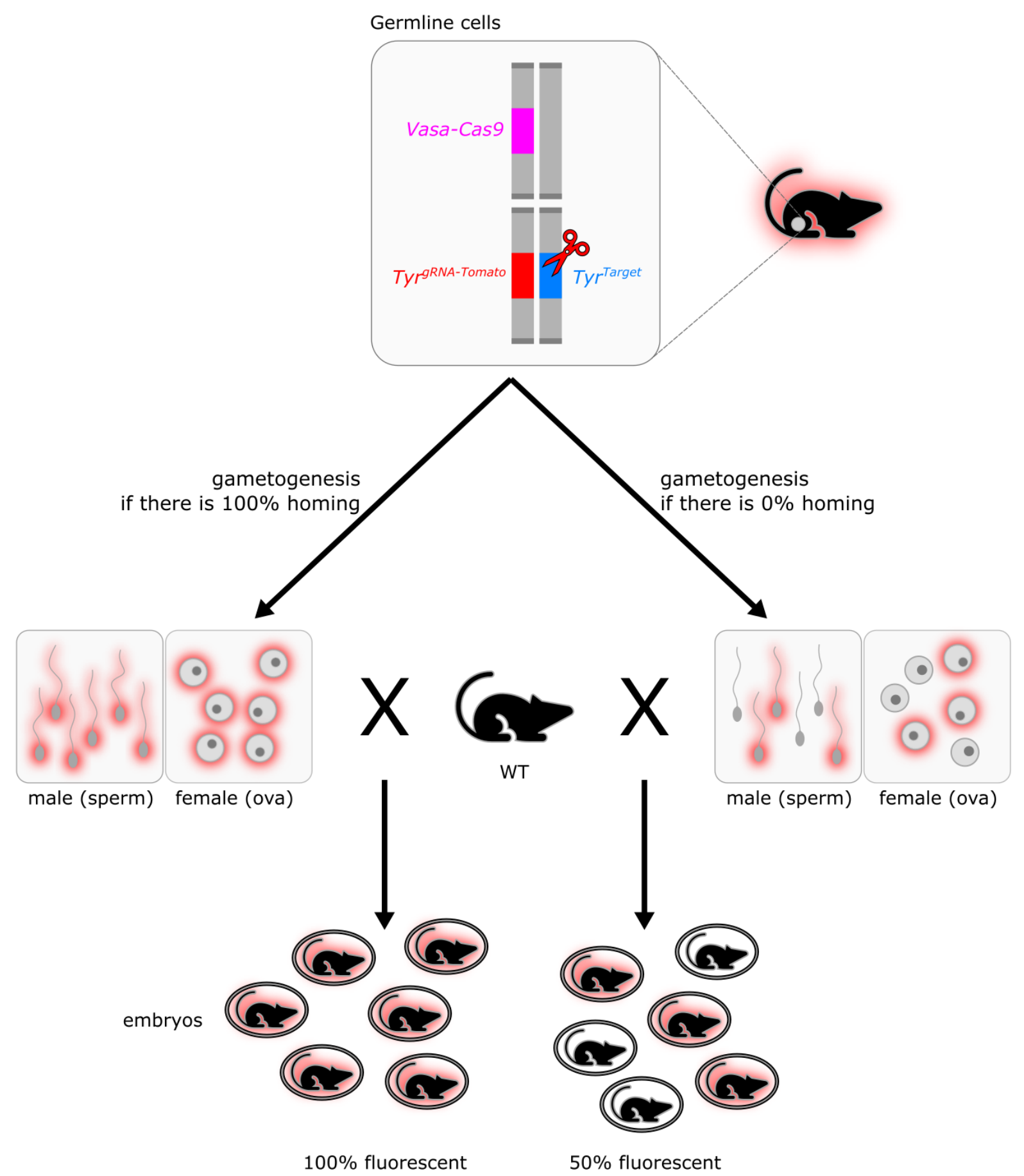

Figure 3. Germline-homing gene drive activity. Experimental mice (top right) contain Vasa-Cas9, Tyr ${ }^{\text {gRNA-Tomato }}$, and Tyr ${ }^{\text {Target }}$ alleles. Somatic tissue will not express Cas9 and thus maintain an intact

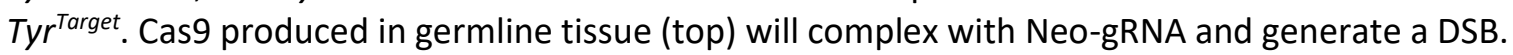
DNA repair mechanisms would then either copy the Tyr ${ }^{\text {gRNA-Tomato }}$ allele over from the donor chromosome (homing) or create an indel (Tyr ${ }^{\text {Target }}$ ). The sperm and ova produced (middle) are shown in the two most extreme alternative possibilities, $100 \%$ or $0 \%$ homing. The actual homing percent is calculated after crossing the original mouse with a WT mouse and counting the number of fluorescent offspring. 


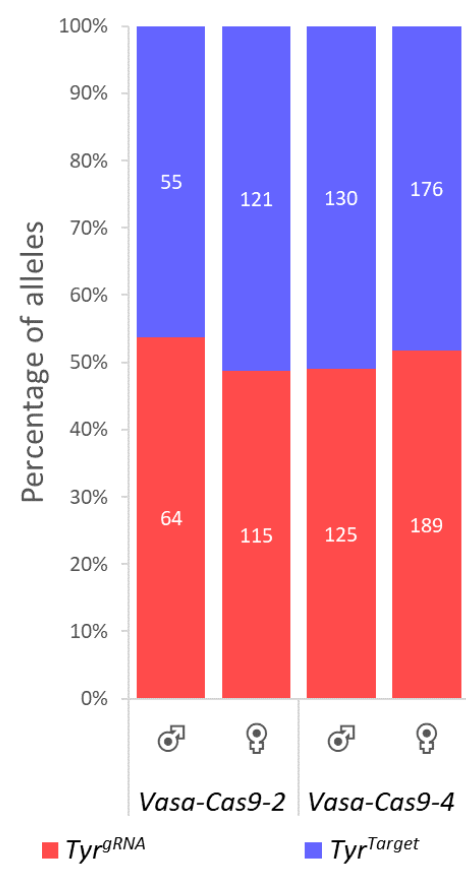

Figure 4. Germline-homing genotyping data. Bar graph showing the percentage of different alleles in the offspring of gene drive mice Vasa-Cas9-2/+ ; Tyr ${ }^{\text {RNNA-Tomato/Target }}$ and Vasa-Cas9-4/+ ; Tyr ${ }^{\text {gRNA-Lite/Target }}$. Total number of offspring shown in columns.

To investigate if higher Cas9 expression levels would promote germline homing, we generated an additional Vasa-Cas9 mouse line (Vasa-Cas9-4). Expression analysis showed a similar Cas9 mRNA level to Vasa-Cas9-2 in the testes but 30 fold higher Cas9 mRNA levels in ovaries (Supplemental Figure 6A), possibly due to the higher transgene copy number (Supplemental Figure 6B). Germline homing experiments were performed as described for Vasa-Cas9-2 except with a shorter donor construct (Tyr ${ }^{\text {gRNA-Lite) }}$ lacking the dTomato expression cassette (see Materials and Methods). Offspring from Vasa-Cas9-4/+ ; Tyr $^{\text {gRNA-Lite/Target }} \mathrm{x}$ WT matings were genotyped by PCR (Figure 4, Supplemental Table 2). Altogether we screened 620 offspring from 10 transgenic males (255 offspring) and 10 transgenic females (365 offspring). Similar to Vasa-Cas9-2, no significant increase ( $\chi^{2}$ test) in Tyr $^{\text {gRNA-Lite }}$ transmission above $50 \%$ was detected from transgenic males $(49.0 \%, p=0.80)$ or females $(51.8 \%, \mathrm{p}=0.53) .87 .1 \%$ of $T y r^{\text {Target }} /+$ male offspring carried indels at the target locus compared with $11.0 \%$ of Tyr Target/+ female offspring (Supplemental Figure 7A,

Supplemental Table 2). Finally, to investigate whether a low level of homing was occurring in Vasa-Cas9-4/+ ; Tyr ${ }^{\text {gRNA-Lite/Target }}$ male mice, we investigated whether $>50 \%$ of sperm carried the Tyr ${ }^{\text {GRNA-Lite }}$ allele using ddPCR (Figure 5). No difference in Tyr ${ }^{\text {gRNA-Lite }}$ level between sperm and control somatic (ear) was detected, indicating an absence of homing. 


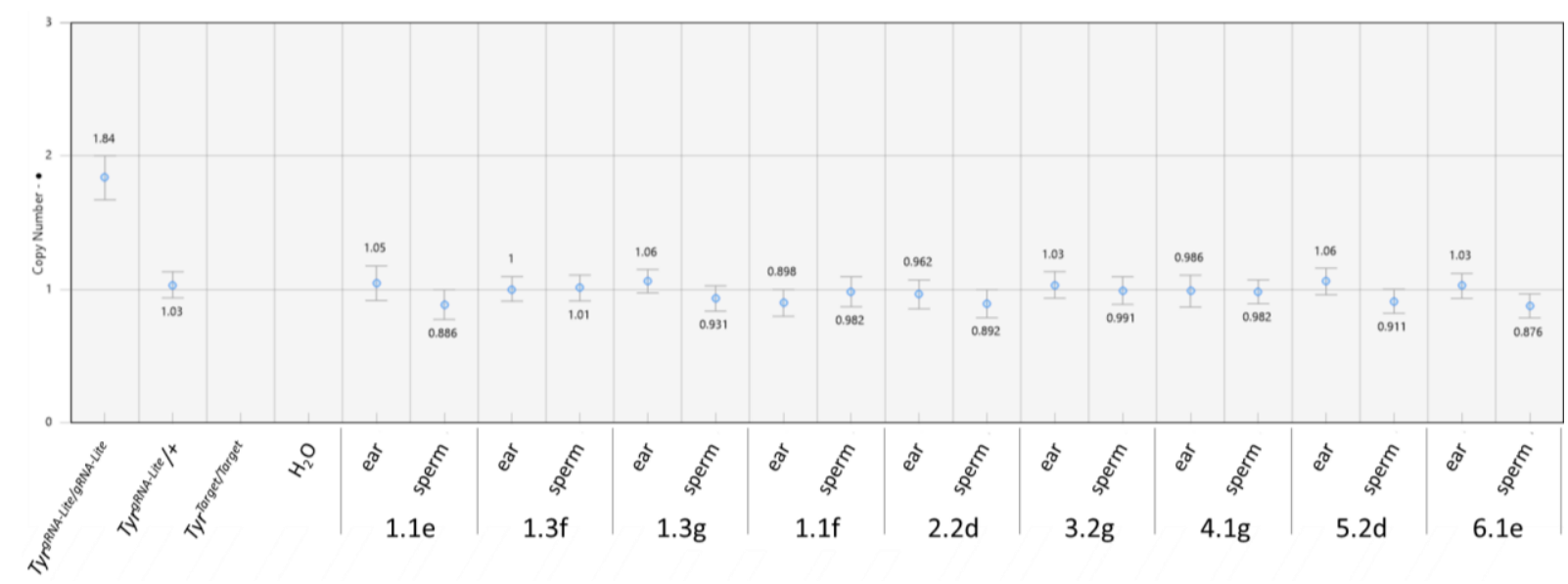

Figure 5. Tyr ${ }^{\text {gRNA-Lite }}$ ddPCR assay. Comparison of Tyr ${ }^{\text {gRNA-Lite }}$ levels in genomic DNA from somatic tissue (ear) and sperm from Vasa-Cas9-4/+ ; Tyr ${ }^{\text {gRNA-Lite/Target }}$ mice.

\section{Discussion}

\section{Zygotic Homing}

While the vast majority of gene drive experiments have employed germline promoters to drive Cas9, it is also notionally possible for homing to occur in the zygote. Indeed, targeted integration of dsDNA templates can occur (albeit inefficiently) in zygotes, confirming that HDR is active in the early embryo (Yang et al. 2013). Further, it has recently been reported that "interhomolog repair" (effectively the same process as gene drive homing), can occur in human embryos ( $M a$ et al. 2017), although concerns have been raised about the interpretation of these results (Egli et al. 2018) and (Adikusuma et al. 2018). In our experiments using the constitutive CAG promoter, we find no evidence of homing in zygotes despite the high efficiency of DSB generation (>95\% of Rosa $26^{\text {Cas }} /++$; Tyr ${ }^{\text {gRNA-Tomato/Target }}$ mice have indels). Thus, we conclude that error-prone repair pathways predominate over HDR in the early embryo, consistent with the recent observations of (Grunwald et al. 2019). While this DSB repair bias may reflect the availability of endogenous DNA repair proteins, the separation of the donor and receiver alleles into distinct pronuclei until after $G_{2}$ phase (1820 hours after fertilisation) (Ciemerych and Sicinski 2005) would also limit the opportunity for zygotic homing to occur.

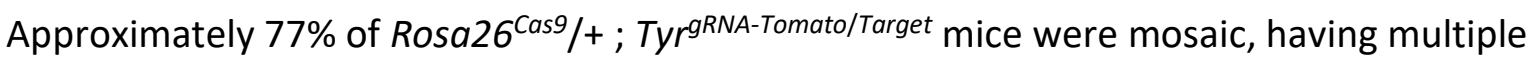
Tyr ${ }^{\text {Target }}$ alleles, including many with $>3$ alleles. Zygotic chromosomes are transcriptionally repressed until the $G_{2}$ phase (Jukam et al. 2017) which delay the formation of the gRNA/Cas9 complex until after $\mathrm{S}$ phase or cell division, resulting in mosaicism. The strength of the CAG and U6 promoters may also be limiting, resulting in insufficient gRNA/Cas9 complex formation and/or translocation to the Tyr ${ }^{\text {Target }}$ locus in the zygote. It is also possible that flawless NHEJ-mediated DNA repair occurs in a proportion of zygotes thereby delaying the generation of indels until the 2-cell stage or later. Surprisingly, given that the Cas9 and gRNA promoters are constitutive, $5 \%$ of Rosa $26^{\operatorname{Cas}^{\circ} /+} ;$; Tyr ${ }^{\text {gRNA-Tomato/Target }}$ mice had an intact Tyr ${ }^{\text {Target }}$ allele and a further $34 \%$ had a mix of both intact alleles and indels. This suggest that flawless NHEJ-mediated DNA repair occurs at a relatively high level in somatic cells. In the 5 mice that were free of indels, continued production of EGFP (linked to Cas9 via P2A) indicates that Cas9 protein is still being produced, and continued production of dTomato tells us there is no gene silencing happening in the region of Neo-gRNA transcription 
bioRxiv preprint doi: https:/doi.org/10.1101/2020.06.21.162594: this version posted June 21,2020 . The copyright holder for this preprint (which was not certified by peer review) is the author/funder, who has granted bioRxiv a license to display the preprint in perpetuity. It is made available under aCC-BY-NC-ND 4.0 International license.

Page 11 of 14

(Supplemental Figure 8), although it is possible that specific downregulation of the U6 promoter (for Neo-gRNA) may be occurring or increased Cas 9 mRNA/protein degradation may occur through unknown mechanisms.

It is possible that carryover of maternal mRNA or protein could have influenced the probability of homing and the developmental stage at which indels are generated. However, we found no evidence for a difference in indel frequency or timing in Rosa $26^{\operatorname{Cas} 9} /+$; $T_{\text {Ty }}{ }^{\text {RRNA-Tomato/Target }}$ mice based on the parental origin of the Cas9 or gRNA expression alleles (Supplemental Figure 9).

\section{Germline Homing}

Studies in D. melanogaster, $A$. stephensi and $A$. gambiae have shown that homing can occur with high efficiency when Cas9 expression is driven in the germline using promoter fragments (Gantz and Bier 2015; Gantz et al. 2015; Hammond et al. 2016). Here we used a similar strategy to express Cas9, employing the $5.6 \mathrm{~kb}$ murine Vasa proximal promoter, which is one of the few characterised mammalian promoter fragments that is expressed in the male and female germline (Gallardo et al. 2007). In contrast to insects, transmission of the donor allele was not statistically higher than $50 \%$ in either of the Vasa-Cas9 lines. While this does not completely rule out homing, it is clear that it is not occurring at a substantial or useful level.

Although significant homing did not occur, sufficient Cas9 was produced to generate indels in the Tyr ${ }^{\text {Target }}$ allele in some germ cells. Analysis of Cas9 levels revealed that transgene expression was much higher in testes than ovaries for both Vasa-Cas9 lines, in contrast to the published Vasa-Cre line (Gallardo et al. 2007). Consistent with the sexually dimorphic expression level of each line, indel generation was higher in males than females. However, it remains unclear why indels were generated much more frequently in the Vasa-Cas9-4 line versus Vasa-Cas9-2 given that transgene expression in the testes was similar.

Recent studies indicate the level and timing of Cas9 expression in the germline is critical for homing efficiency. It is thought that homing is most likely to occur during meiosis when homologous chromosomes are aligned for meiotic recombination (Grunwald et al. 2019). Generation of DSBs before or after meiosis instead promotes generation of indels via errorprone repair pathways. As the timing of meiosis is sex-specific, activity of the Vasa transgene must be considered in both males and females. It has previously been shown that the Vasa promoter fragment is strongly induced at E15-18 in testes and before P3 in ovaries (Gallardo et al. 2007). In the E15-18 testes, primordial germ cells (PGCs) are undergoing mitotic proliferation and don't enter meiosis until P9 (Hilz et al. 2016). As a consequence, Vasa expression is likely too early for homing, consistent with the high frequency of indels that we observed in both Vasa-Cas9 lines. In contrast, nascent oocytes enter meiosis at E13.5, moving through zygotene to pachytene before they arrest at $\sim E 19$ in dictyotene, which is maintained until P21 (Hilz et al. 2016). As alignment of homologous chromosomes is maintained throughout this period, homing should be promoted. Why then did we not observe Super-Mendelian transmission of the Tyr ${ }^{g R N A}$ alleles in females? The answer probably relates to the very low level of transgene expression in the ovary, which, despite the substantial transgene copy number, was barely above background levels. Given only $9 \%$ and $11 \%$ of female Vasa-Cas9 offspring carried indels, the frequency of DSB generation in the female germline was likely very low and homing rarely occurred if at all. It is also possible that the Vasa promoter is activated too early in the ovary given that endogenous 
bioRxiv preprint doi: https:/doi.org/10.1101/2020.06.21.162594: this version posted June 21, 2020. The copyright holder for this preprint (which was not certified by peer review) is the author/funder, who has granted bioRxiv a license to display the preprint in perpetuity. It is made available under aCC-BY-NC-ND 4.0 International license.

Page 12 of 14

Vasa expression starts at E10.5-11.5 in PGCs of both sexes (Tanaka et al. 2000). Notably, in contrast to our results, a similar study by Grunwald et al. (2019) did observe homing in females (although not in males). An important difference between our study and Grunwald et al. (2019) is their use of the Vasa-Cre line to express Cas9 from the CMV promoter via removal of a stop-flox cassette. Thus, Cas9 levels are likely much higher in the Grunwald et al. (2019) experiment.

In conclusion, based on our observations and those of Grunwald et al. (2019), we suggest that zygotic homing is not a feasible strategy in mice. Efficient homing in the germline will require identification of additional promoters, ideally with robust and specific expression during meiosis in oocytes and spermatocytes. Thus, considerable experimental development is required before rodent gene drives can be considered for deployment to address conservation, agricultural or health objectives.

\section{Acknowledgements}

This study was funded by a US Defense Advanced Research Projects Agency (DARPA) "Safe genes" grant to Paul Thomas. The authors thank John Godwin and members of the Genetic Biocontrol for Invasive Rodents consortium for useful discussions during the course of this research project. The authors acknowledge the facilities and the scientific and technical assistance of the South Australian Genome Editing (SAGE) Facility, the University of Adelaide and the South Australian Health and Medical Research Institute. SAGE is supported by the Australian Phenomics Network (APN). The APN is supported by the Australian Government through the National Collaborative Research Infrastructure Strategy (NCRIS) program.

\section{References}

Adikusuma, F., S. Piltz, M. A. Corbett, M. Turvey, S. R. McColl et al., 2018 Large deletions induced by Cas9 cleavage. Nature 560: E8-E9.

Akbari, O. S., H. J. Bellen, E. Bier, S. L. Bullock, A. Burt et al., 2015 Safeguarding gene drive experiments in the laboratory. Science 349: 927-929.

Blackburn, T. M., P. Cassey, R. P. Duncan, K. L. Evans and K. J. Gaston, 2004 Avian Extinction and Mammalian Introductions on Oceanic Islands. Science 305: 1955-1958.

Burt, A., and V. Koufopanou, 2004 Homing endonuclease genes: the rise and fall and rise again of a selfish element. Curr Opin Genet Dev 14: 609-615.

Champer, J., R. Reeves, S. Y. Oh, C. Liu, J. Liu et al., 2017 Novel CRISPR/Cas9 gene drive constructs reveal insights into mechanisms of resistance allele formation and drive efficiency in genetically diverse populations. PLoS Genet 13: e1006796.

Charron, Y., J. Willert, B. Lipkowitz, B. Kusecek, B. G. Herrmann et al., 2019 Two isoforms of the RAC-specific guanine nucleotide exchange factor TIAM2 act oppositely on transmission ratio distortion by the mouse t-haplotype. PLoS Genet 15: e1007964.

Ciemerych, M. A., and P. Sicinski, 2005 Cell cycle in mouse development. Oncogene 24: 2877-2898.

Cong, L., F. A. Ran, D. Cox, S. Lin, R. Barretto et al., 2013 Multiplex genome engineering using CRISPR/Cas systems. Science 339: 819-823.

DiCarlo, J. E., A. Chavez, S. L. Dietz, K. M. Esvelt and G. M. Church, 2015 Safeguarding CRISPR-Cas9 gene drives in yeast. Nat Biotechnol 33: 1250-1255.

Doherty, T. S., A. S. Glen, D. G. Nimmo, E. G. Ritchie and C. R. Dickman, 2016 Invasive predators and global biodiversity loss. Proc Natl Acad Sci U S A 113: 11261-11265. 
Egli, D., M. V. Zuccaro, M. Kosicki, G. M. Church, A. Bradley et al., 2018 Inter-homologue repair in fertilized human eggs? Nature 560: E5-E7.

Gallardo, T., L. Shirley, G. B. John and D. H. Castrillon, 2007 Generation of a germ cellspecific mouse transgenic Cre line, Vasa-Cre. Genesis 45: 413-417.

Gantz, V. M., and E. Bier, 2015 The mutagenic chain reaction A method for converting heterozygous to homozygous mutations. Science 348: 442-444.

Gantz, V. M., N. Jasinskiene, O. Tatarenkova, A. Fazekas, V. M. Macias et al., 2015 Highly efficient Cas9-mediated gene drive for population modification of the malaria vector mosquito Anopheles stephensi. Proc Natl Acad Sci U S A 112: E6736-6743.

Gregory, S., W. Henderson, E. Smee and P. Cassey, 2014 Eradications of vertebrate pests in Australia, pp. 1-90. Invasive Animals Cooperative Research Centre, Canberra, Australia.

Grunwald, H. A., V. M. Gantz, G. Poplawski, X. S. Xu, E. Bier et al., 2019 Super-Mendelian inheritance mediated by CRISPR-Cas 9 in the female mouse germline. Nature 566: 105-109.

Hammond, A., R. Galizi, K. Kyrou, A. Simoni, C. Siniscalchi et al., 2016 A CRISPR-Cas9 gene drive system targeting female reproduction in the malaria mosquito vector Anopheles gambiae. Nat Biotechnol 34: 78-83.

Harris, D. B., 2008 Review of negative effects of introduced rodents on small mammals on islands. Biological Invasions 11: 1611-1630.

Hilz, S., A. J. Modzelewski, P. E. Cohen and A. Grimson, 2016 The roles of microRNAs and siRNAs in mammalian spermatogenesis. Development 143: 3061-3073.

Hsu, P. D., D. A. Scott, J. A. Weinstein, F. A. Ran, S. Konermann et al., 2013 DNA targeting specificity of RNA-guided Cas9 nucleases. Nat Biotechnol 31: 827-832.

Jukam, D., S. A. M. Shariati and J. M. Skotheim, 2017 Zygotic Genome Activation in Vertebrates. Dev Cell 42: 316-332.

Kelemen, R. K., and B. Vicoso, 2018 Complex History and Differentiation Patterns of the tHaplotype, a Mouse Meiotic Driver. Genetics 208: 365-375.

Ma, H., N. Marti-Gutierrez, S. W. Park, J. Wu, Y. Lee et al., 2017 Correction of a pathogenic gene mutation in human embryos. Nature 548: 413-419.

Platt, R. J., S. Chen, Y. Zhou, M. J. Yim, L. Swiech et al., 2014 CRISPR-Cas9 knockin mice for genome editing and cancer modeling. Cell 159: 440-455.

Prowse, T. A. A., P. Cassey, J. V. Ross, C. Pfitzner, T. A. Wittmann et al., 2017 Dodging silver bullets: good CRISPR gene-drive design is critical for eradicating exotic vertebrates. Proc Biol Sci 284.

Ran, F. A., P. D. Hsu, J. Wright, V. Agarwala, D. A. Scott et al., 2013 Genome engineering using the CRISPR-Cas9 system. Nat Protoc 8: 2281-2308.

Shaner, N. C., R. E. Campbell, P. A. Steinbach, B. N. Giepmans, A. E. Palmer et al., 2004 Improved monomeric red, orange and yellow fluorescent proteins derived from Discosoma sp. red fluorescent protein. Nat Biotechnol 22: 1567-1572.

Sinkins, S. P., and F. Gould, 2006 Gene drive systems for insect disease vectors. Nat Rev Genet 7: 427-435.

Stenseth, N. C., H. Leirs, A. Skonhoft, S. A. Davis, R. P. Pech et al., 2003 Mice, rats, and people: the bio-economics of agricultural rodent pests. Frontiers in Ecology and the Environment 1: 367-375. 
bioRxiv preprint doi: https://doi.org/10.1101/2020.06.21.162594 t this version posted June 21, 2020. The copyright holder for this preprint (which was not certified by peer review) is the author/funder, who has granted bioRxiv a license to display the preprint in perpetuity. It is made available under aCC-BY-NC-ND 4.0 International license.

Page 14 of 14

Tanaka, S. S., Y. Toyooka, R. Akasu, Y. Katoh-Fukui, Y. Nakahara et al., 2000 The mouse homolog of Drosophila Vasa is required for the development of male germ cells. Genes Dev 14: 841-853.

Wu, S., G. Ying, Q. Wu and M. R. Capecchi, 2008 A protocol for constructing gene targeting vectors: generating knockout mice for the cadherin family and beyond. Nat Protoc 3: 1056-1076.

Yang, H., H. Wang, C. S. Shivalila, A. W. Cheng, L. Shi et al., 2013 One-step generation of mice carrying reporter and conditional alleles by CRISPR/Cas-mediated genome engineering. Cell 154: 1370-1379. 